\title{
A Study In to the Influence of Performance Factors on Performance Ratings: An Institutional Catering Perspective of Public Universities in Western Kenya
}

\author{
Were Simon O \\ Masinde Muliro University of Science and Technology \\ *Corresponding Author: Were Simon $\mathbf{O}$, Masinde Muliro University of Science and Technology
}

\begin{abstract}
Catering is an essential service, and thus subsidized to enable equitable and affordable higher education, with the KUCCPS students in focus. However, there has been an outcry from university's management, with some outsourcing their catering services, while others revamping these services under the income generating units (IGU's). This has been due to the increase in demand for university education leading to immense pressure on the catering services as public universities have resolved to open their doors to the Privately Sponsored Programs (PSSPS) concurrent with the Kenya Universities and Colleges Central Placement Services (KUCCPS). This however resulted to unprecedented changes and multiple challenges, basically in provision of catering services, within the institutional catering framework, directly visible on the diminishing performance ratings. This study therefore was guided by four objectives; to investigate the influence of Human Capital on performance ratings of catering services within public universities in western Kenya., to examine the effect of public funding on performance ratings of catering services within public universities in western Kenya., to analyze the impact of the menu on performance ratings of catering services within public universities in western Kenya, and to establish the moderating effect of Government policy on the relationship between the influence of performance factors on performance ratings of catering services within public universities in western Kenya. Data was coded, analyzed and presented via descriptive statistics and inferential statistics. The results of the study shows there is influence of performance factors on performance ratings in catering services within public universities in western Kenya. Consequently, the results of the study depicts there is a moderating effect of government policy on the relationship between performance factors and performance ratings within public universities in western Kenya.
\end{abstract}

Keywords: Performance factors, Institutional Catering, Performance ratings

\section{INTRODUCTION}

Mbirithi (2013) asserts that demand for university education continues to increase not only in Kenya but worldwide, while at the same time competition for access rises each year, which ultimately causes immense pressure on the catering services offered in public universities. This is as a result of increased student population through the Privately Sponsored Programs (PSSP) which runs concurrently with the Kenya Universities and Colleges Central Placement Services (KUCCPS), (Ministry of Education and Ministry of Higher Education, 2012). Never the less, the UNESCO report, (2000) reiterates that the concept of University education must comprise the aspects of affordable food and accommodation provision, especially in the third world countries like Kenya, where majority of households are hard hit by abject poverty.

For this reason, catering services are considered essential, and thus together with accommodation and tuition, are subsidized to enable equitable and affordable higher education to all Kenyans, with the KUCCPS students in focus. Indeed, for higher learning institutions to achieve high quality education, these two variables; catering and accommodation are paramount. Nevertheless, public universities have of the recent past been grappling with provision of catering services to their students, as it has become uneconomical through the losses accrued from these businesses. There has been an outcry across the country from university management, with some universities outsourcing their catering services (Sang 2012), while others revamping these services under the income generating units (IGU's). Different universities across the country have employed different strategies to overcome these chal- 
lenges, with the main aim of improving the performance ratings of catering services in terms of financial output, client satisfaction and curbing the production costs.

\section{LITERATURE REVIEW}

As the 21st century unfolds, Kenyan Public Universities are undergoing unprecedented changes and confront multiple challenges, basically in provision of catering services, within the institutional catering framework. Catering facilities in Public Universities, commonly referred to as "messes", have a responsibility to ensure provision of subsidized wholesome food and beverages, which is affordable to the entire students' market segment. These catering facilities, works with the objective of breaking even, meaning that all overhead costs must be met by the operation, including; electricity bills, water bills, fuel costs, and all capital investments within the department.

On the contrary, there are issues of massive losses incurred by these institutional catering facilities across all the public universities. In general, they have had massive challenges, and this is directly visible on the diminishing performance ratings including; very low financial output, escalated production costs and low level of client satisfaction and hence retention. Thus, in view of the current status of the institutional catering services within the Kenyan public universities, production costs are unbearable, the financial output is unsustainable, and worst of it all, customer satisfaction is wanting, suggestive of the perceived poor quality menu on offer, and thus pushing these customers to other alternative catering options on the one side, while on the other, prompting the University management to reduce on both capital and current expenditure as a result of fear.

Although, some catering management gurus have indicated the influence of PSSPs', which is not factored in the subsidy equation, and subsequently by respective university management in an effort to explain the ever widening variance between total costs of production and the resultant total revenue achieved. Thus basing on this argument, the government subsidies on the catering services are entirely for the KUCCPS students. This therefore suggests that the PSSP students could be enjoying the subsidized catering services without directly contributing to the footing of the subsidy costs in the fees charged for the various academic programs.

This study therefore investigated the influence of performance factors; Human Capital, public funding, and the menu, on performance ratings of catering services in public universities; financial output, Client Satisfaction and production costs. Consequently, the study examines the moderating effect of Government policy; subsidies, procurement laws and price control, on the relationship between the key studies variables.

\subsection{Performance Factors}

The quest to understand the determinants of performance within the institutional catering framework has created divergent views including the structural characteristics of catering institutions and firmspecific resources such as capital; both human and financial (Jeremy \& Peter 2008). However, in recent years, the nature of competition and the shifting of economic conditions have led to increased challenges of the assumptions upon which industry structure theories have been built, and especially with the catering services within public universities whose core function is to provide wholesome, subsidized and thus affordable food and beverages to bonafide students.

Jeremy et al (2008) confirms that in today's business environment, arguments suggest that structural characteristics of industries are becoming less relevant determinants of performance while firm resources are becoming the basis upon which firms compete. These include human capital, funding, as well as the menu, which is mainly the selling tool. Furthermore, Mbirithi (2013) postulates that in service firms such as hospitality, resources are found to be much more important to explaining performance variation than in manufacturing firms. Consequently, Jeremy et al (2008) extrapolates further by confirming that in both manufacturing and services firms, intangible assets and capabilities explain performance variation while, as hypothesized, tangible resources do not. In line with this argument, the following is a review of these resources in relation to their influence on performance of catering services in public universities in western Kenya;

\subsubsection{Human Capital}

An amalgam of organizations across the world has developed tools for measuring their performance in order to continue in business and face off tough competition. Institutional Catering services within 
the Kenyan public universities are not an exemption, as they too face stiff competition from informal private commercial catering services on the outskirts, and to some extent from within the universities in form of outsourced catering services. Moreover, these catering organizations face not only more demanding conditions in the current period to the world financial crisis as well (Iveta 2012), which calls for prudent human capital management.

Organizations try to evaluate performance in accordance to the financial drivers, but in the recent period top leaders attempted to find new performance indicators which would get the "wind from sail" to their competitors in the market, human capital, being one of the competitive advantages. Tootell, B., Blackler, M., Toulson, P. \& Dewe, P. (2009) states that "since 1980s there has been an increasing emphasis on the importance of HR measurement." In addition, Yeung and Berman (1997) declared that "HR measures should be impact rather than activity orientated, forward looking than backward looking, and should focus on the entire HR system not just on individual practices." However, the main point of contention is how and to what extend these human capital assets of institutional catering contributes to the general performance ratings of catering services within public universities in Kenya.

\subsubsection{Factors for Evaluating Human Performance}

The factors of examining human performance vary from industry to industry. The hospitality industry being labor intensive (Lillicrap et al 2010), requires evaluation factors that can provide overall development of work force thereby achieving its strategic and management goals as suggested by Varun \& Linu (2014). Some of the factors that affect performance of human resource in institutional catering services within public universities are as discussed below.

\subsubsection{Competency}

Competency is the ability of an individual employee to perform a job properly, with minimal supervision but maximum performance. It is the sum of all observable and measurable personal traits, professional skills, knowledge of an employee ; which he/she contribute to work and ultimately benefits the organization that employ them. Competency based assessment provide clarity in performance analysis. Competencies bridge the gap between performance management and employee development and are a fundamental component of personal growth plans. Competency records can be used for employee development, compensation, promotion, training and new hire selection decisions within the hospitality sector. This attribute of catering services employees directly affects the end product of institutional catering, and thus customer satisfaction and retention. On institutional Catering services basis, it may be looked upon in terms of relevant skills in housekeeping and property management, customer care, general supervisory and management skills, as well as food production, sales and service.

\subsubsection{Attitude}

Job attitude is a set of evaluations that constitute ones feelings, beliefs and attachment to a particular job. There are two particular job attitudes namely job satisfaction and organizational commitment that influence ones behavior towards a job. In professional jobs such as hospitality, there exist a stronger link between work attitudes and performance, as opposed to manual non-professional jobs. Correlation between work attitudes and performance is important and has practical value. People who are organized, reliable, dependable, and achievement-oriented seem to outperform their colleagues.

\subsubsection{Quality}

Quality is a measure of excellence or a state of being free from defects, deficiencies and significant variation in a product. It is brought about by strict and consistent commitment to certain standards that achieve uniformity of a product in order to satisfy specific catering consumer or user requirements. Quality in institutional catering services refers to three things namely getting the job done on time, product output based on client requirements, and ensuring breaking-even of the catering business (Lillicrap et al. 2010).

Quality of the ingredients used in food production, efficiency and effectiveness of the kitchen brigade, food and beverage service staff, the housekeeping and/ or cleaning staff, the supervisors and other skilled and unskilled laborers defines the success of an institutional catering facility. Application of total quality management can improve the quality aspects within the institutional catering services of 
the hospitality sector. A shift in the behavior and culture of the workforce especially senior management in this sector of the hospitality industry is necessary to improve its performance. Implementation of TQM in catering services can be achieved only through cultural change.

\subsubsection{Productivity}

Productivity is a measure of the efficiency of a person, machine, factory or system in converting inputs into useful outputs. Productivity is an average measure of efficiency of production and may be expressed as the ratio of output to input used in the production process. The operational procedure of the catering services is complicated in nature. This industry consists of professionals involved in different phases of food production, sales and service including seconded staff from finance, procurement as well as other sections such as maintenance. All these cadres of staff have to play their respective role to deliver quality catering services. In the entire global hospitality industry, there must be team work for any success to be achieved.

\subsubsection{Ethics}

This can be both business ethics and personal ethics, both are interrelated. Hospitality industry has specific professional ethics, which refers to the responsibilities and procedures to be followed by a group of people involved in food production, sales and service with regard to the organization they work and the public at large. Hospitality professionals within institutional catering services are not exempt from common ethical behaviors like obligations, duties and responsibilities-that are binding on hospitality staff, and are usually bound by a set of principles, attitudes or types of character dispositions that control the way the profession is practiced. As long as the lack of professionalism and ethics remains, even the ethically good will have difficulty to adhere to moral code of conduct.

\subsubsection{Funding}

Public universities in Kenya, receive Government support and therefore have to abide by certain laws and regulations that apply to public institutions for example, procurement, and transparency in recruitment of staff, in a bid to ensure maximum and broad participation by Kenyans whose tax funds are used to support them (Ministry of Education and Ministry of Higher Education, 2012). On the other hand, some public policies advocates that university engages in other Income Generating Activities (IGAs) to boost their revenue base, so long as participation in those activities does not pull resources or detract the universities from their core business. Thus funding of the catering services within public universities in Kenya is twofold;

\subsubsection{Public Funding}

Kenyan public universities have been, and are beneficiaries of public funding through the ministry of higher education. Funding of these universities is through capitation from the exchanger, grants as well as loans. However, there has been immense pressure on resources, with the increasing numbers of public universities as well as Kenyan students seeking higher education in these institutions, and thus as a result leading to diminishing funding from the government (Sifuna, 1998). Accordingly, public funding emphasizes subsidies on tuition rather than other basic services such as catering services.

There has been an ever swelling population of Kenyan citizens qualifying for university education, and as such the need for capital investments (Ishengoma, 2004). However, it's worth noting that the government subsidies, particularly meant for catering services may only be in terms of salaries paid to catering staff, but no other financial boost is availed directly to the catering sections in public universities. Thus in majority, if not all public universities, the government subsidy cannot be quantified and therefore product pricing has never been accurate, as a basis of ensuring these institutions break-even.

\subsubsection{Privately Sponsored Students Programs (PSSP)}

Kiamba (2004) confirms that this program developed as a result of low financial allocation from the Government. The cost of staff, learning and research material, food and lodging, coupled with inflationary pressures made it difficult to sustain the operations of universities. 


\subsubsection{The Menu}

According to, Lillicrap \& Cousins (2010), the menu must meet three objectives of the marketing policy, catering policy as well as the financial policy. Though, there have been issues with the menu on offer within institutional catering facilities in Kenyan public universities, hence one of the foremost causes of sleepless nights to the University management as well as catering departmental heads;

\subsubsection{Menu Item Quality}

Quality in the menu items on offer is undisputable if any catering outlet is to remain an industry leader in their specific market segment. Conversely, across the mainstream of catering institutions, the focal clientele has been dissatisfied with quality of food that is prepared and served. Nonetheless, in view of the explanation of the perceived poor quality products, it is largely attributed to the procurement laws which lead to purchasing of low quality products at high prices as this is mainly on the lowest bidder basis. In some instances, catering facilities have to bear the costs incurred as a result of middle-men (Mbirithi 2013) instead of buying directly from key distributors, as this might raise eyebrows on accusation on single sourcing which is objectionable by the procurement law.

There are also concerns on the failure of suppliers to deliver due to price fluctuations, while there has been a failure to get back quotation responses from suppliers on certain food items hence depriving the menu off varieties on the one hand and quality on the other hand, especially if the food item is a major ingredient. All these reasons have culminated into poor catering services as a result of poor quality food for sale and service by the institutional catering facilities. Yet, some accusation has been directed on the catering brigade as the cause for poor quality menu items as a result of their incompetence.

\subsubsection{2. Мепи Variety}

Menu variety within the institutional catering facilities is vital especially in provision of options for the larger base of clients. However, catering for a group of people is fiddly as the menu must capture the needs of the majority of the clientele, and thus needs much attention and effort in planning. This becomes more challenging if the same group of clientele stays for longer durations, a minimum being four years within these institutions. Given the diverse economic as well as gastronomic backgrounds (Sang 2012), whatever seems variety to the caterer may not actually satisfy the needs of the entire market segment, but only a percentage of the clientele may show some satisfaction. Thus as a caterer within institutional catering facilities, one is expected to strike a balance in the provision of foods, which cuts across the economic, gastronomic, ethnic, gender as well as age divide. Moreover, it becomes tricky especially for the catering teams who always have to operate within specific budget constraints.

\subsection{Performance Ratings}

There are numerous indicators that can be used to measure performance of any business establishment, and specifically the catering related business. Included are the financial output, client satisfaction as well as production costs.

\subsubsection{Financial Output}

Were Simon O (2016) asserts that commercial catering establishments must be able to ensure return on investment, while on the other hand, institutional catering establishments must ensure they breakeven for sustainability of the business. This can only be achieved in the presence of a stable market segment that provides enough demand for the products as well as proper product pricing that covers all the costs. Tamara \& Birnbaum (2013) postulate that catering is a significant revenue source at these institutions, and, at least in concept, these funds are used to offset operating costs.

It is quite evident that some menu items are under-priced in some public Universities, such that in comparison with the expected revenue from the prepared portions, a direct loss is incurred. In the Commercial catering outlets, prices are frequently adjusted to cater for any inflation that may result causing increases in the costs concerned. However, institutional catering facilities in public universities are expected to operate on the basis of breaking-even, as this is the concept of institutional catering globally. As a result, all the costs of production are to be borne by the institutional catering operation (Tamara et al, 2013). 


\subsubsection{Client Satisfaction}

Parasuraman (2000) denotes that customer satisfaction is supreme in any business set up, and this is only on the basis of product quality and product price. In business, the customer is referred to as the king (Kelly 2009), and as such, the main objective in institutional catering business is to ensure client satisfaction, and thus retention. Phillip Kotler (2016) confirms that the best advertising is done by satisfied customers. This also applies to institutional catering services within public universities. In fact, according to Sada (2015), average customer with a complaint tells nine to ten people who are potential clients, and thirteen percent $(13 \%)$ tell more than twenty people thus indeed a confirmation of the cost of dissatisfied customer.

Quality of the food within the institutional catering facilities has been an issue to the clientele, some crying out due to poor quality food products, while others are concerned with lack of menu variety as well as portion size. According to Francis (2015), static menus in institutional catering becomes boring and thus non receptive by the market segment, thus suggestive of menu varieties to keep the market segment satisfied and thus retained.

\subsubsection{Production Costs}

Production costs of institutional catering facilities have been pummeling with time as a result of ever increasing student population, while catering facilities menu prices on the other hand have remained static for over decades (Francis 2015). The need for more staff to work on an average of two shifts a day has sky-rocketed, purchase of equipment is paramount, and the food cost is currently unbearable in relation to menu prices. Francis (2015) ascertains that some universities such as the University of Nairobi have opted to outsource catering services in an attempt to revamp the catering business, under the Income generating units (IGU). This has ultimately given birth to two parallel results; the first being loss of initial purpose for provision of subsidized institutional catering services especially to the needy Government sponsored students, and the second is the transfer of institutional catering problems and troubles to the boards of management of the IGUs.

Even though some public universities have adopted various strategies to bail these catering facilities out of the unbearable production costs, an example being Kenyatta University, who have opted to open a myriad of food outlets out of the subsidy equation, so as to enable these institutions reduce on the ever swelling costs of production. This is mainly with the aim of ensuring that catering sections break-even, as a result of the gains from economies of scale. However, with all these mitigation strategies in place, the challenge of unprecedented production costs is prone to persist in case menu prices remains as it is without any price reviews being carried out.

\subsection{Government Policy}

This is through price controls as a result of the subsidies offered by the Government, not forgetting the procurement laws enforced by the creation of independent departments dealing with all procurement issues within the public universities.

\subsubsection{Subsidies}

The government committed herself to equitable provision of quality education to all her citizens through government sponsorship, and thus subsidized university education. This was initially managed through the Joint Admissions Board (JAB), which was ultimately transformed to Kenya Universities and Colleges Central Placement Services (KUCCPS) (Republic of Kenya 2009). As such, the same subsidy trickled down not only in the academic line but also in essential services including catering services as well as accommodation. It was until the year 1995 that the Kenyan government shifted the burden of higher education costs from being borne predominantly by government, or taxpayers, to being shared with parents, students and the private sector (Republic of Kenya, 2010), hence the birth of cost sharing policy that saw the introduction of pay as you eat (PAYE) program in public universities. Nevertheless, even after operationalization of the cost sharing policy, the government introduced the Higher Education Loans Board (HELB) to facilitate the cost sharing policy for the students who could not raise the percentage that was to be borne by the parents.

With increased demand for higher education, Public universities opened their doors for the privately sponsored students through the privately sponsored students program in addition to the government 
sponsored students, with different fee rates for the two programs. The main aim for introduction of the PSSP was to aid universities raise cash, and thus income generating. Kiamba (2004) reveals that to date, there is no single public university in Kenya that possesses differentiated unit costs for the degree programs they offer, which may be used as a guideline in estimation of the fees to be paid for a specific program by both the PSSP as well as KUCCPS students.

\subsubsection{Procurement Laws}

The procurement department was formulated through the public procurement act which mandated the department to carry out all procurement activities within the public sector. Thus procurement functions are required to follow the public procurement act (Republic of Kenya 2009), where the catering section participates in the development of purchase specifications as well as receiving of the goods, while the rest of the activities in the acquisition of the goods, is carried out by the procurement department. In majority of the public institutions, award of tenders is on the basis of the lowest bidders. Nonetheless, the so called lowest bidders are still expensive as stressed by Ogot (2002), compared to buying directly from the market, processing and/ or manufacturing firms. Even though the payment period is normally stipulated on the tender documents (Balbachoosky n.d), there has been a series of outcries all over about delayed payments, running into years as a result of either lack of funds or staff laxity and/ or corrupt deals.

\subsubsection{Price Control}

Price control is a government effort to avoid exploitation of customers by service providers and institutions (Republic of Kenya 2009). The Government of Kenya, through specific university councils as well as management boards, has the responsibility to set and approve menu prices which are pocket friendly to all the university students. Price control has seen catering services stick to their original menu prices from the time of inception to date, and in some instance, for decades without factoring in inflation that causes increase in prices of goods as well as production costs. As a result, sales from certain prepared food items do not realize the purchasing cost of the raw food, even without factoring in overhead costs, thus resulting to losses. Consequently, price control is the genesis of poor quality food within the institutional catering services (Sang 2012) as low quality food supplies are preferred so as to minimize the loss percentages by catering sections within public universities.

\section{Materials ANd Methods}

\subsection{Research Design}

A cross-sectional survey design, concerned with examining variation across cases (Henn et al, 2009), as well as a descriptive correlation research survey, which allows the researcher to describe and evaluate the relationship between the study variables by asking questions to the respondents and examining their relationships were adopted. Eric, Alan, Shankar \& Christine (2008) asserts that crosssectional research survey involves using different groups of factors which differ in the variable of interest, which formed the DV of the study (performance factors) but share other characteristics. Consequently, descriptive correlation research design was instrumental in examining performance ratings of the institutional catering facilities. Factors under investigation were performance factors (IV) influencing performance indicators (DV), and government policy as MV.

\subsection{Study Area}

For the purpose of this study, the western circuit consists of thirteen counties including: Trans-Nzoia, Bungoma, Kakamega, Vihiga, Busia, Nandi, Kisumu, Siaya, Homa Bay, Migori, Kisii, Kericho and Nyamira (Isaac M.N, Warkach K.T \& Stephen G.A, 2016). The region is also known for the production of rice, maize meal, wheat, tea, beans and sugar in relatively large quantities. Thus in view of agricultural activities, it is purely a commercial agricultural region, with huge contributions towards the country's food security as it is normally referred to as the "granary" of the nation. The Western region was chosen because of her stable, reliable and favorable climate that has seen the region immensely contribute towards the Country's food security. Therefore, very little price fluctuations are experienced within this region unlike other regions in Kenya, which are severely affected by price fluctuations due to lack and/or limited supply of the main food crops. 


\subsection{Target Population}

This constituted the Institutional Catering facilities within public universities in the western parts of Kenya. The population from which respondents were drawn included institutional catering services staff, with a specific focus on catering managerial staff within this public university's catering services departments. In addition, the students' welfare services staff as well the students catering representatives were considered.

\subsection{Sampling Techniques}

It would have been desirable to use a census of the whole population of the public universities in Kenya, which are spread countrywide but owing to such limitations as the distances to be covered to each of the universities, the costs that would be involved in covering them and the given time frame among other reasons, the researcher focused on the public universities within the Western region of Kenya, thus including all public universities within the former Western and Nyanza provinces which formed the Western region of the country.

\subsection{Sample size}

The following formula was used to calculate the sample size;

$$
\begin{aligned}
& \boldsymbol{n}=\frac{N}{1+N\left(e^{2}\right)}, \text { Where } \mathrm{n}=\text { Desired sample size } \\
& \text { study) } \\
& \qquad \mathrm{N}=\text { Population, thus } \mathrm{N}=156 \text { (From the thirteen Public Universities under the } \\
& \mathrm{e}=\text { Accepted range of error set at statistical significance, thus e }=0.05
\end{aligned}
$$

$$
\begin{aligned}
& \text { Thus: } \boldsymbol{n}=\frac{156}{1+156\left(0.05^{2}\right)} \\
& =113 \text { Respondents }
\end{aligned}
$$

\subsection{Research Instruments}

\subsubsection{Questionnaires}

For the purpose of this study, the questionnaire comprised both closed-ended as well as open ended questions (Henn et al, 2009), aiming at investigating performance ratings of catering units within public universities. This allowed the respondents greater freedom of expression, in relation to the influence of performance factors on performance ratings of catering services within public universities in western region, Kenya, under investigation. The questionnaire comprised of four sections; with the first section based on gathering data on personal information of the respondents in regard to the designation, length of service at the current station, and general contribution on supervisory and service delivery to the clients. The second section narrowed down on investigating the performance factors that influence performance ratings of the catering services within public universities set-up, while the third section was to assess the performance ratings of the catering services, based on impact of the performance indicators within this public universities' catering services departments. Lastly, the fourth section focused on establishing the moderating effect of the various government policy factors on the provision of catering services within the catering departments of public universities in the western region, Kenya.

\section{RESULTS AND DISCUSSIONS}

The results of the study were presented, analyzed and interpreted in the context of the purpose of the study and the hypothesis formulated. The objectives of the study were to investigate the influence of institutional catering performance factors on the performance ratings in public universities within western Kenya.

\subsection{Demographic Characteristics of the Respondents}

From the study findings (Table 4.1), most of the respondent's designations within the university were caterers $(46.0 \%)$, other staff $(26.0 \%)$, senior caterers $(15.0 \%)$, and catering officers $(13.0 \%)$. The summary is as shown in Table 4.1. 
A Study In to the Influence of Performance Factors on Performance Ratings: An Institutional Catering Perspective of Public Universities in Western Kenya

Table4.1. Designation within the university

\begin{tabular}{|l|l|l|l|l|l|}
\hline & & Frequency & Percent & Valid Percent & Cumulative Percent \\
\hline \multirow{4}{*}{ Valid } & Catering Officer & 13 & 13.0 & 13.0 & 13.0 \\
\cline { 2 - 6 } & Senior Caterer & 15 & 15.0 & 15.0 & 28.0 \\
\cline { 2 - 6 } & Caterer & 46 & 46.0 & 46.0 & 74.0 \\
\cline { 2 - 6 } & Others & 26 & 26.0 & 26.0 & 100.0 \\
\cline { 2 - 6 } & Total & 100 & 100.0 & 100.0 & \\
\hline
\end{tabular}

On investigating the length of time the respondents have been in the designated position, $50 \%$ of the respondents were found to have been in their designated position for a period of 6 months to three years, $26 \%$ of the respondents three to five years, $13 \%$ for less than six months, and $11 \%$ for more than five years. This shows that the respondents have sufficient knowledge on the performance factors that influence performance ratings of catering services in public universities based on the experience gained.

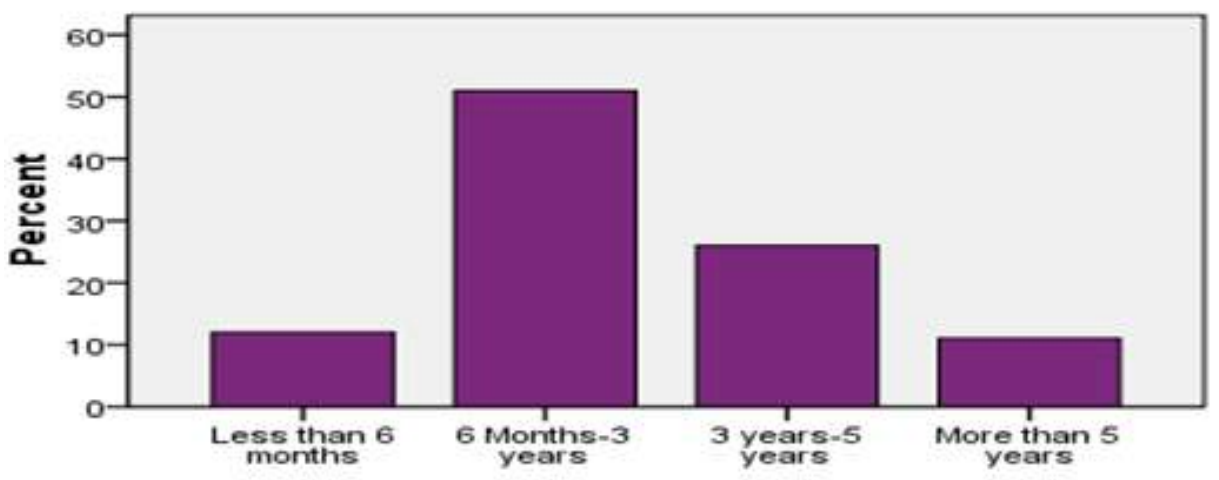

Figure1. Position held in the institution

In relation to the number of catering staff the respondents supervise, $32 \%$ of the respondents were found to be directly or indirectly supervising 11-19 staff, $23 \%$ of the respondents were found to be supervising 6-10 people, and $13.0 \%$ less than 6 people. This shows that majority of the respondents were directly or indirectly supervising catering services staff within the university. The summary of the findings is as shown in Table 4.2.

Table4.2. Number of catering services staff directly or indirectly supervised

\begin{tabular}{|l|l|l|l|l|l|}
\hline & Frequency & Percent & Valid Percent & Cumulative Percent \\
\hline \multirow{5}{*}{ Valid } & Less than or equal to 5 people & 13 & 13.0 & 13.0 & 13.0 \\
\cline { 2 - 6 } & 6-10 People & 23 & 23.0 & 23.0 & 36.0 \\
\cline { 2 - 6 } & $11-19$ People & 32 & 32.0 & 32.0 & 68.0 \\
\cline { 2 - 6 } & More than or equal to 20 People & 32 & 32.0 & 32.0 & 100.0 \\
\cline { 2 - 6 } & Total & 100 & 100.0 & 100.0 & \\
\hline
\end{tabular}

The results show that $32 \%$ of the respondents were found to be supervising 11-19 catering services staff. Consequently, $32 \%$ of the respondents were also found to be supervising more than or equal to 20 catering services staff either directly or indirectly.

\subsection{Performance Factors Influencing Performance Ratings of Catering Services within Public Universities in Western Kenya}

The study sought to investigate the influence of performance factors on the performance ratings of catering services within public universities. This was guided by three objectives;

i. To determine the influence of Human Capital on the performance ratings of Catering services within Public Universities in Western Kenya

ii. To examine the effect of public funding on the performance ratings of catering services within public universities in Western Kenya 
iii. To investigate the impact of the menu on performance ratings of catering services within public universities in Western Kenya.

Basing on a five-likert scale, respondents were requested to indicate whether they agreed; to no extent at all, to a small extent, to a moderate extent, to a large extent and finally to a very large extent. Data was analyzed and presented as in the table 4.3 below.

Table4.3. Influence of Performance factors on the performance ratings of Catering services

\begin{tabular}{|c|c|c|c|c|c|}
\hline & 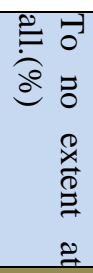 & 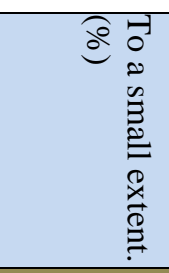 & 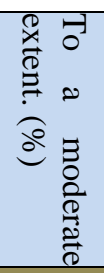 & 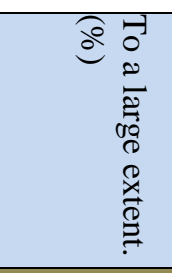 & 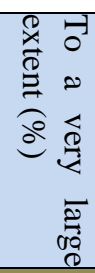 \\
\hline Competency of the catering services personnel & 1.0 & 4.0 & 22.0 & 53.0 & 20.0 \\
\hline Attitude of the catering services employees & 2.1 & 12.3 & 14.2 & 15.4 & 56.0 \\
\hline $\begin{array}{l}\text { Quality of individual catering services employee's work } \\
\text { output }\end{array}$ & 0.4 & 2.0 & 13.4 & 34.2 & 50.0 \\
\hline Productivity level of each catering services employee & 1.6 & 3.1 & 20.0 & 53.3 & 22.0 \\
\hline $\begin{array}{l}\text { Work ethics e.g. against corrupt practices among cater- } \\
\text { ing employees }\end{array}$ & 2.1 & 11.8 & 22.6 & 38.1 & 20.3 \\
\hline $\begin{array}{l}\text { Public funding through the ministry to the Universities } \\
\text { catering services }\end{array}$ & 0.4 & 2.0 & 13.4 & 34.2 & 50.0 \\
\hline $\begin{array}{l}\text { University funding from the PSSP to the catering servic- } \\
\text { es }\end{array}$ & 1.0 & 4.0 & 22.0 & 53.0 & 20.0 \\
\hline $\begin{array}{l}\text { Quality of the menu items produced for sale in the cater- } \\
\text { ing units }\end{array}$ & 2.1 & 12.3 & 14.2 & 15.4 & 56.0 \\
\hline $\begin{array}{l}\text { Varieties in the menu provided by the catering services } \\
\text { units }\end{array}$ & 1.0 & 2.0 & 0.0 & 32.0 & 65.0 \\
\hline
\end{tabular}

4.2.1. To Determine the Influence of Human Capital on the Performance Ratings of Catering Services within Public Universities in Western Kenya

The first objective sought to determine the influence of Human Capital on the performance ratings of Catering services within Public Universities in Western Kenya, on the basis of; competency of the catering services staff, Attitude of the catering services employees, quality of individual catering services employee's work output, productivity level of each catering services employee, and work ethics. The results (table 4.3 above) show that attitude of the catering services employees influences performance ratings of Institutional catering services within public universities to a very large extent (56\%), Productivity level of each catering services employee to a large extent (53.3\%) and competency of the catering services personnel to a large extent (53\%). On the other hand, the results from the likert scale showed that quality of individual catering services employee's work output influences performance ratings to no extent at all $(0.4 \%)$, competency of the catering services personnel to no extent at all $(1.0 \%)$, and productivity level of each catering services employee to no extent at all (1.6\%). Averagely, the study reveals that human capital influences performance ratings of catering services by; $39.0 \%$ to a large extent, $34.0 \%$ to a very large extent, $18.5 \%$ to a moderate extent, $7.0 \%$ to a small extent and $1.5 \%$ to no extent at all. Thus, from the study findings, human capital influences performance ratings of catering services within public universities by $98.5 \%$.

According to Al-jabari (2012), it is well-known that Human Resource Management is the only living factor of production, and responsible of controlling the other factors within any organization. This is also echoed by Lillicrap and Cousins (2010) who alludes that the hospitality industry is labor intensive, and the same applies to institutional catering services. In the same manner, for efficiency and effectiveness of institutional catering services within the public universities, human capital remains the key determinant of performance, and hence the driving force behind the success of catering services within public universities in. A number of studies have identified several Human resource (HR) practices and challenges that managers face in executing their jobs, and have used these findings to 
provide theoretical and practical insights from a developing country context (Ghebregiorgis and Karsten, 2006); although relatively little research has focused on human capital aspect in relation to the performance of institutional catering services within public universities not only in Kenya but also the world over of, and thus this study intended to fill up the knowledge gap.

\subsubsection{To Examine the Effect of Funding on the Performance Ratings of Catering Services within Pub- lic Universities in Western Kenya}

The second objective sought to examine the effect of funding on the performance ratings of catering services within public universities in Western Kenya; on the basis of public funding through the ministry to the universities catering services, and university funding from the PSSP to the catering services. The findings (table 4.3) shows that public funding through the ministry influence catering services to a very large extent (50\%) and University funding from PSSP to the catering services influences catering service to a large extent (53\%). Thus from the results of the study, $99.6 \%$ of the respondents depicts that public funding influences catering services within public universities, while $99.0 \%$ shows that funding from PSSP influences catering services within public universities.

However, Kiamba (2004) confirmed that to date; the Kenyan public universities do not posses any tangible revised differentiated unit cost (DUC) for the degree programs on offer, on which reference would be made as to how much is charged on the PSSP as well as KUCCPS students to cater for the subsidies on catering services. Although there have been arguments on the government subsidies for the KUCCPS students, emphasis is normally placed on tuition during program cost estimates unlike catering services and therefore no funding is provided to the catering services sections in public universities from PSSP students, even though they also enjoy subsidized catering services.

\subsubsection{To Investigate the Impact of the Menu on Performance Ratings of Catering Services within Public Universities in Western Kenya.}

Lastly on performance factors, the third objective sought to investigate the impact of the menu on performance ratings of catering services within public universities in Western Kenya; on the basis of quality of the menu items produced for sale in the catering units as well as varieties in the menu provided by the catering services units. From the study results, quality of the menu items produced for sale in the catering units influences catering services to a very large extent $(56 \%)$ while Varieties in the menu provided by the catering services units influences catering service within universities to a very large extent $(65 \%)$.

Generally, an average of $98 \%$ of respondents indicated that there is an influence of menu quality on performance ratings of catering services within public universities while $99 \%$ of the study results show that menu variety influences performance ratings of catering services within public universities. In reference to the study findings by Were Simon O (2016) and Flayyih \& Sada (2015) with the findings of this study, they both concur that the menu is an indispensable tool for sales as it is essential for the development of production plan, hence formulation and preparation of the menu depends on the taste and the art of selection of dishes based on the premeditated foundations.

\subsubsection{Hypothesis Testing}

In order to test the relationship between the key study variables, the following null hypothesis were formulated and tested; there is no influence of; Human Capital, funding and the menu on the performance ratings of catering services within public universities in Western Kenya

To test the null hypothesis that there is no influence of; human capital, public funding and the menu, on the performance ratings of catering services within public universities in Kenya, a linear regression analysis was carried out and tested at 5\% significance level.

Table4.4. Model Summary

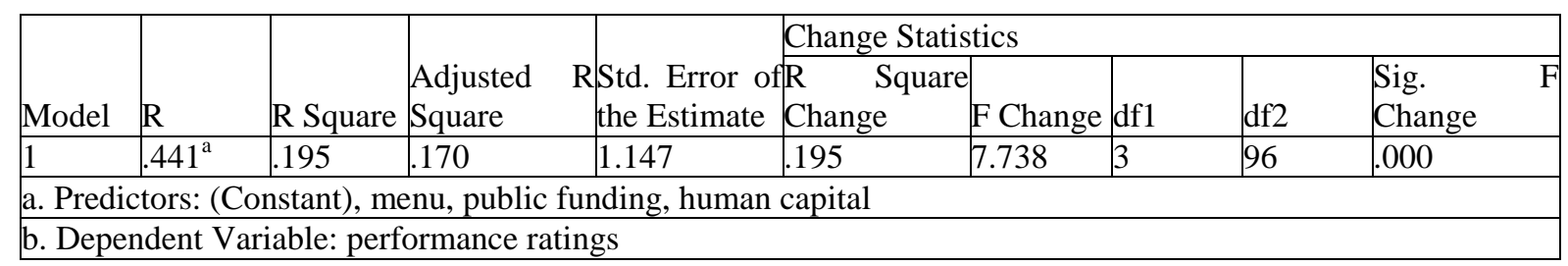


From the analysis, $\mathrm{R}^{2}$ is 0.195 or $19.5 \%$ which imply that there is a relationship between human capital, public funding and menu with performance ratings is small.

Table4.5. ANOVA

\begin{tabular}{|l|l|l|l|l|l|l|}
\hline Model & Sum of Squares & df & Mean Square & F & Sig. \\
\hline 1 & Regression & 30.555 & 3 & 10.185 & 7.738 & $.000^{\mathrm{b}}$ \\
\cline { 2 - 7 } & Residual & 126.355 & 96 & 1.316 & & \\
\cline { 2 - 7 } & Total & 156.910 & 99 & & & \\
\hline \multicolumn{2}{l|l}{ a. Dependent Variable: performance ratings } \\
b. Predictors: (Constant), menu, public funding, human capital \\
\hline
\end{tabular}

From the analysis, the $\mathrm{F}$ value of 7.738 is greater than the significance value of 0.05 , therefore the study failed to reject the three hypotheses that there is no influence of human capital, funding and the menu on the performance ratings of catering services within public universities in western Kenya. Thus, there being a variation between human capital, funding, and the menu with performance ratings of catering services in public universities, and that the variation cannot explain the relationship

Table4.6. Regression Analysis

\begin{tabular}{|c|c|c|c|c|c|c|}
\hline \multirow{2}{*}{\multicolumn{2}{|c|}{ Model }} & \multicolumn{2}{|c|}{ Unstandardized Coefficients } & \multirow{2}{*}{$\begin{array}{l}\begin{array}{l}\text { Standardized Coef- } \\
\text { ficients }\end{array} \\
\text { Beta } \\
\end{array}$} & \multirow{2}{*}{$\mathrm{T}$} & \multirow[b]{2}{*}{ Sig. } \\
\hline & & $\mathrm{B}$ & Std. Error & & & \\
\hline \multirow[t]{4}{*}{1} & (Constant) & 7.071 & 1.599 & & 4.421 & .000 \\
\hline & human capital & .167 & .068 & .288 & 2.469 & .015 \\
\hline & Funding & .082 & .061 & .155 & 1.339 & .184 \\
\hline & Menu & .205 & .125 & .153 & 1.640 & .104 \\
\hline
\end{tabular}

The coefficient table was used to determine whether the relationship between human capital, public funding and the menu, with performance ratings is significantly related and the strength of their relationship. Thus from the regression analysis, human capital with a significance value of $0.015<0.05$, the study rejected the null hypothesis and concludes that there is an inluence of human capital on performance ratings of catering services within public universities in Kenya, with a t value of 2.469, which signifies the relative importance of each human capital factors in the model. On the other hand, the results of the regression analysis gave t values of 1.339 and 1.640 on funding and the menu respectively which implies the relative importance of the menu, followed by funding in that order, and significance values of 0.184 and 0.104 thus sig. $>0.05$, and hence the study failed to reject the two null hypotheses and concluded that; there is no influence of public funding on the performance ratings of catering services within public universities in Western Kenya, and there is no influence of the menu on the performance ratings of catering services within public universities in Western Kenya respectively.

\subsubsection{To Establish the Moderating Effect of Government Policy on the Relationship between Perfor- mance Factors and Performance Ratings of Catering Services in Public Universities in the Western Kenya.}

The study sought to determine whether there is moderating effect of Government policy on the relationship between the influence of performance factors on the performance ratings of catering services within public universities in Kenya. To test the null hypothesis that there is no moderating effect of government policy on the relationship between the influence of performance factors on performance ratings of catering services within public universities in Kenya, a linear regression analysis was carried out at 5\% significance level and the results tabulated as in table 4.7, 4.8 and 4.9 below.

Table4.7. Model Summary

\begin{tabular}{|c|c|c|c|c|c|c|c|c|c|c|}
\hline \multirow[b]{3}{*}{ Model } & \multirow[b]{3}{*}{$\mathrm{R}$} & \multirow[b]{3}{*}{ R Square } & \multirow{3}{*}{$\begin{array}{l}\text { Adjusted } \\
\text { Square }\end{array}$} & \multicolumn{6}{|c|}{ Change Statistics } & \multirow{3}{*}{$\begin{array}{ll}\text { Sig. } & \text { F } \\
\text { Change }\end{array}$} \\
\hline & & & & RStd. Error o & $\mathrm{R} \quad \mathrm{S}$ & Square & & & & \\
\hline & & & & the Estimate & Change & & F Change & df1 & df 2 & \\
\hline 1 & $.270^{\mathrm{a}}$ & .073 & .054 & 1.651 & .073 & & 3.829 & 2 & 97 & .025 \\
\hline
\end{tabular}


A Study In to the Influence of Performance Factors on Performance Ratings: An Institutional Catering Perspective of Public Universities in Western Kenya

Table4.8. $A N O V A$

\begin{tabular}{|l|l|l|l|l|l|l|}
\hline Model & Sum of Squares & Df & Mean Square & F & Sig. \\
\hline \multirow{5}{*}{1} & Regression & 20.874 & 2 & 10.437 & 3.829 & $.025^{\mathrm{b}}$ \\
\cline { 2 - 7 } & Residual & 264.436 & 97 & 2.726 & & \\
\cline { 2 - 6 } & Total & 285.310 & 99 & & & \\
\hline
\end{tabular}

Table4.9. Regression Analysis

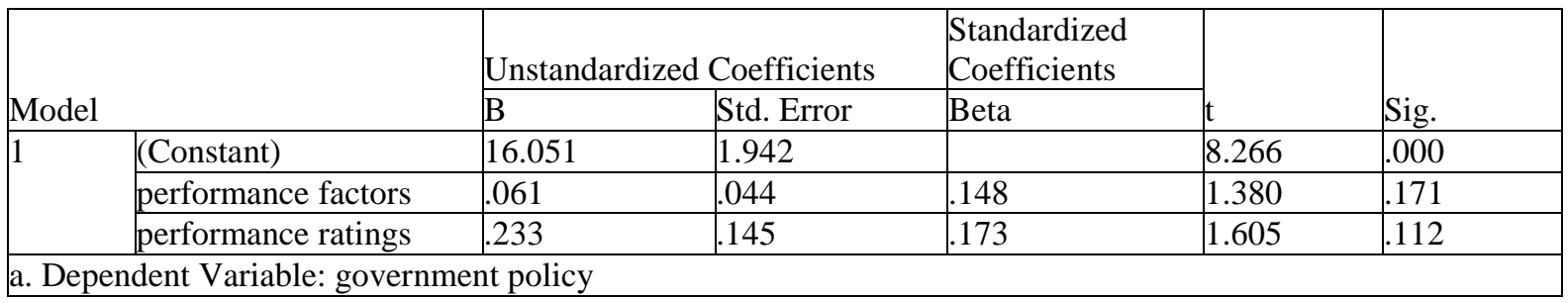

From the analysis, $\mathrm{R}^{2}$ is 0.073 or $7.3 \%$ which signify that the moderating effect of government policy on the relationship between performance factors and performance ratings is small. However, the magnitude of the relationship should never be assumed, and especially in today's competitive business structures. Mbirithi (2013) postulates that the Government of Kenya has laid down policies that not only controls operations in the catering sections within institutional catering services, but also provides guidelines on the general management of institutional catering facilities, either directly or indirectly through other legal sections within the public university set-up, which this study finds out to be having a moderating effect on the performance ratings.

\section{CONClusion}

From the study findings, the results shows that performance factors; including human capital, funding as well as the menu influences performance ratings; financial output, client satisfaction and production costs by over $95 \%$, and therefore calls for much attention in the catering services within public universities. Consequently, although the study revealed a weak relationship on the moderating effect of government policy on the relationship between performance factors and performance ratings, the moderating variables; subsidies, procurement laws as well as price controls by the government through specific university councils should never be assumed as it is justified by there being a relationship, and hence a moderating effect of the government policy on the relationship between the two key study variables.

\section{REFERENCES}

[1] Al-Jabari, M. ". (2012). Factors affecting human resource practices in a sample of diversified palestinian organizations. Tourism and Management Studies International Conference Algarve vol.2 , 595-603.

[2] Balbachoosky, Elizabeth. (June 2014). Challenges fo Public and Private Higher Education.Issue No: 320

[3] Birnbaum, T. Y. (2013). The challenges of student affairs. Journal of Student Affairs in Africa $\mid$ Volume 1 (1\&2), 33-48.

[4] Eric Rindfleisch, A. M. (2008). Cross-sectional Versus Longitudinal Survey Research: Concepts, Findings and Guidelines. Journal of Marketing Research, 261-272.

[5] Francis Ofunya Afande, F. M. (2015). Drivers for Effectiveness of outsourcing of Catering Services in Public Hospitals in Kenya. The Internal Journal of Public Policy and Administration Research, Vol. 5 No.4, 12-36.

[6] Ghebregiorgis, F. \& Karsten, L. (2006). Human resource management practices in Eritrea: challenges and prospect. Employee Relations, 28 (2), 144-63.

[7] Isaac Mamboh Nyamwano, Warkach Kipkorir Tanui \& Stephen Gaya Agong (2016). The hidden treasures of Kenya's Western Tourist Circuit as opportunitities for Ecotourism Development. International Journal of Liberal Arts and Social Sciences, Vol. 4 NO. 2 , 103-123

[8] Ishengoma. (2004). Cost Sharing in Higher Education in Tanzania. Fact or Fiction? Journal of Higher Education in Africa, Vol. 2, Issue 2 , 20-75. 
[9] Iveta, G. (March 2012). Human Resources Key Performance Indicators. Journal of Competitiveness Vol. 4, Issue 1 , pp. 117-128.

[10] Jowi, J. O. (2009). Internationalization of Higher Education in Africa: Developments, emerging trends, issues and policy implementation. Higher Education Policy, 263-281.

[11] Kelly, M. (2009, October 15th ). The Customer is King. Claims Advisor: Information for today's claims professionals, pp. 1-4.

[12] Kiamba, C. (2004). Challenges and Opportunities in the Management of the University of Nairobi. Seminar of the University of Nairobi senate (pp. 1-102). Nairobi, Kenya: University of Nairobi.

[13] Lillicrap, D., \& Cousins, J. (2010). Food and Beverage Service, 8th Ed. London: Hodder Education.

[14] Mbirithi, D. M. (2013). Management Challanges facing Kenya's public Universities and implications for the quality of education. Nairobi: Kenyatta University.

[15] Ministry of Education and Ministry of Higher Education, S. a. (2012). A policy Framework for Education and Training, Reforming Education and Training in Kenya. Nairobi: Governement Publishers.

[16] Ogot, B. (2002). The Enterprise University: Real or Pseudo? Seminar of the First exhibition by Kenyan Universities (pp. 3-25). Nairobi, Kenya: University of Nairobi printing Press.

[17] Parasuraman. (July-September 2000). Superior Service and Marketing Excellence: Two sides of the Same Success Coin. The Journal for Decission Makers Vol. 5, No. 3, 3-33.

[18] Phillip Kotler, Bowen and Makens. (2016). Marketing for Hospitality and Tourism (7th Edition). Guilds: Pearson.

[19] Republic of Kenya. (2009). Kenya Education Sector Program. Nairobi, Kenya: Government Press.

[20] Republic Of Kenya. (2010). Economic Survey, 2009 \& 2010. Nairobi: Government Press.

[21] Sada, D. N. (2015). Analysis of the menus' factors that are influential in increasing the volume of sales : an empirical study on first-class restaurants in baghdad. European Scientific Journal, December edition, Vol. 8 No. 28 , 45-60

[22] Sang, D. J. (November 2012). Outsourcing in Kenyan Universities: An examination of Challenges and Opportunities. International Journal of Bussiness and Social Sciences, Vol.1, No. 2 , 204-212.

[23] Sifuna, D. (2006). The Governance of Kenyan Public Universities. Research in Post-Compulsory education , 175-212

[24] Tootell, B., Blackler, M., Toulson, P. \& Dewe, P. (2009). Metrics: HRM's Holy Grail? A New Zealand case study. Human Resources Management Journal, 19(4), 375-392. http://dx.doi. org/10.1111/j.17488583.2009.00108.x

[25] Varun .V. (2014). Factors and Methods for Performance Evaluation of Human Resource in Construction Industry. International Journal of Scientific Engineering and Research (IJSER), 59-62.

[26] Were Simon O, (2016). Cultural Determinants of Food Choices by hospitality clientele in Commercial catering outlets within Kisumu County, Kenya. International Journal of Novel Research in Interdisciplinary Studies, Vol. 3, Issue 6 , pp: (1-14).

[27] World Bank. (2010). Financing Higher Education. Washington DC 20433: The International Bank for Reconstruction and Development / The World Bank.

[28] Yeung, A.K. \& Berman, B. (1997). Adding value through human resources: reorienting human resources measurement to drive business performance. Human Resource Management, 36 (3), 321-335. http://dx.doi.org/10.1002/(SICI)1099-050X(199723)36:3<321::AIDHRM4> 3.3.CO;2-2

Citation: Were, Simon O. "A Study in to the Influence of Performance Factors on Performance Ratings: an Institutional Catering Perspective of Public Universities in Western Kenya." International Journal of Research in Tourism and Hospitality (IJRTH), vol 3, no. 4, 2017, pp. 30-43. doi:http://dx.doi.org/10.20431/24550043.0304004.

Copyright: (C) 2017 Authors. This is an open-access article distributed under the terms of the Creative Commons Attribution License, which permits unrestricted use, distribution, and reproduction in any medium, provided the original author and source are credited. 